\title{
ЕЛЕКТРИЧНИЙ ТРАНСПОРТ
}

\author{
UDC 629.423:621.313.3 - 047.37
}

\section{O. YU. BALIICHUK ${ }^{1 *}$, L. V. DUBYNETS ${ }^{2}$, O. M. DUKHNOVSKYI ${ }^{3}$, O. O. MARENYCH ${ }^{4}$, O. L. MARENYCH}

\footnotetext{
${ }^{1 *}$ Dep. «Electrical Engineering and Electromechanics», Dnipropetrovsk National University of Railway Transport named after Academician V. Lazaryan, Lazaryan St., 2, Dnipropetrovsk, Ukraine, 49010, tel. +38 (056) 37315 47, e-mail baliichukaleksei@mail.ru, ORCID 0000-0003-0119-1446

${ }^{2}$ Dep. «Electrical Engineering and Electromechanics», Dnipropetrovsk National University of Railway Transport named after Academician V. Lazaryan, Lazaryan St., 2, Dnipropetrovsk, Ukraine, 49010, tel. +38 (056) 37315 47, ORCID 0000-0003-0319-4544

${ }^{3}$ Dep. «Electrical Engineering and Electromechanics», Dnipropetrovsk National University of Railway Transport named after Academician V. Lazaryan, Lazaryan St., 2, Dnipropetrovsk, Ukraine, 49010, tel. +38 (056) 37315 47, e-mail daniel214@ukr.net, ORCID 0000-0001-5087-4206

${ }^{4}$ Dep. «Electrical Engineering and Electromechanics», Dnipropetrovsk National University of Railway Transport named after Academician V. Lazaryan, Lazaryan St., 2, Dnipropetrovsk, Ukraine, 49010, tel. +38 (056) 37315 47, e-mail marenich.alexandra@gmail.com, ORCID 0000-0003-4162-1746

${ }^{5}$ Dep. «Electrical Engineering and Electromechanics», Dnipropetrovsk National University of Railway Transport named after Academician V. Lazaryan, Lazaryan St., 2, Dnipropetrovsk, Ukraine, 49010, tel. +38 (056) 3731547 , ORCID 0000-0003-3602-5851
}

\section{INFLUENCE OF FEEDING ELECTRIC ENERGY QUALITY ON HEATING OF THE AUXILIARY MACHINES OF AC ELECTRIC ROLLING STOCK}

Purpose. The article aims to study the problem of increase the reliability of auxiliary machines for AC electric trains during operation in real conditions. Methodology. The peculiarity of system construction of auxiliary machines for AC electric rolling stock is the use of asynchronous motors for general industrial purpose. An engineering method of influence determination on the feeding voltage asymmetry and its deviation from the nominal value on heating of auxiliary machines insulation was proposed. Findings. It is found out that in case when the auxiliary machines of AC electric trains work under asymmetry factor of the voltage $10 \%$ or more and feeding voltage deviation from the nominal order 0.6 relative unit then it is possible the overheat of their isolation, even if it has class $\mathrm{H}$. Originality. For the first time the issue of the total insulation heating under such boundary parameters combinations of energy quality, when each of them contributes to the heating insulation increase as compared to the nominal regime of the "rotating phase splitter-auxiliary machinery" system was illuminated. Practical value. Conducted research allow us to establish the boundary parameter values of feeding energy quality (asymmetry factor, feeding voltage deviations from the nominal value), at which additional isolation overheating of this class under the effect of specified factors will not exceed the agreed value.

Keywords: overheating; electrical power quality; asymmetry; auxiliary electrical machines; electric stock; AC

\section{Introduction}

Standards of electric energy quality (EQ) in the power supply systems of general purpose are determined by the State Standard 13109 - 97 [3]. Electric locomotives and trains of $\mathrm{AC}$ are equipped with general purposed asynchronous motors (AM) of three-phase current for the auxiliary devices drive (compressors, fans, pumps, etc.). These devices are powered by the phase splitter (the converter of single-phase current into three-phase 
one). At present on AC electric rolling stock (ERS) of Ukrainian railways mainly rotary converters are used. In this case EQ is significantly different from the above mentioned State Standard for the worse. As a result on ERS the AM of general purpose are operated in the toughest conditions. For ERS there are initial developments of static phase converters instead of the rotary ones. But the technical and economic feasibility of modernization of electric locomotives and trains that have already been working for decades on the Ukrainian railways by replacing the rotary converters with static ones is unlikely.

\section{Purpose}

The purpose of the paper is to improve the reliability of auxiliary machines of AC electric rolling stock in the conditions of the real operation on the Ukrainian railways.

\section{Methodology}

A lot of experts investigated the heating of asynchronous motors of auxiliary devices for ERS, which is operated at present $[6,7,12,13,14]$. Investigations of $\mathrm{O}$. A. Nekrasov should be noted as one of the most overall works $[6,7]$. At this the issue of total insulation heat in such combinations of these parameters of EQ, when each of them promotes the increase of insulation heat as compared to the nominal conditions of the system "rotary phase splitter - auxiliary machines" is almost uncovered. The nominal conditions of the system are understood as the conditions with the nominal voltage $(25 \mathrm{kV})[2]$ in the contact network and with all the auxiliary machinery working in the nominal conditions at the same time.

It is proposed the following engineering determination method of the heating temperature of stator winding insulation for auxiliary AE taking into account the additional heating due to poor quality of feeding electric energy.

Additional insulation heat, which results from the unsinusoidality of voltage curve, can be ignored, as the necessary nominal power reserve as a result of heating from currents and magnetic fields of higher harmonics amounts only about $5 \%[6,7]$.

Additional heating of $\mathrm{AE}$ resulting from voltage asymmetry $\Delta \tau_{\mathrm{H}}[5]$ :

$$
\Delta \tau_{\mathrm{H}}=\frac{2 K_{2 U}^{2}}{100} \theta_{1},
$$

where $K_{2 U}-$ is the coefficient of the voltage asymmetry, $\%$.

Coefficient $K_{2 U}$ should be taken as equal to $10 \%$ at the lowest value of supply voltage and $5 \%$ at the greatest value [1].

$\theta_{1}$ - is the average temperature rise of the stator winding $\mathrm{AM}$ in the nominal conditions. It is this temperature determines the thermal state of the engine in terms of reliability, expected service life and overload capability.

$$
\theta_{1}=R_{11} \Delta P_{1}+R_{12} \Delta P_{2}+R_{13} \Delta P_{3},
$$

where $R_{11}, R_{12}, R_{13}$ - are generalized thermal support of equivalent circuit; $\Delta P_{1}, \Delta P_{2}, \Delta P_{3}$-are accordingly the electric losses in stator winding, electric losses in stator winding, electric losses in rotor winding and losses in the steel.

Thermal supports can be calculated using the following empirical expressions:

$$
\begin{gathered}
R_{11} \approx \frac{K}{D_{a 1} \cdot l_{1}} \\
R_{12} \approx R_{13} \approx 0,6 R_{11}
\end{gathered}
$$

$D_{a 1}$ - is the outer diameter of the stator core, $\mathrm{cm}$; $l_{1}-$ is the length of stator core, $\mathrm{cm} ; K-$ is the coefficient that equals to 27 for $\mathrm{AM}$ with the power $0.5 \ldots 10 \mathrm{~kW}$ and 35 for AM with the power $11 \ldots .250 \mathrm{~kW}$.

Losses of AM are distributed by the type per unit as follows [8]:

Electrical losses in stator $\Delta P_{1 *}=0,3$;

Electrical losses in rotor $\Delta P_{2 *}=0,4$;

Losses in magnetic core of stator $\Delta P_{3 *}=0,15$;

Mechanical losses $\Delta P_{\text {Mex* }}=0,15$;

Total power losses $\sum \Delta P=1,00$.

The postheating of AM during the voltage fluctuation [5]:

$$
\Delta \tau_{\text {он }}=60 \cdot \Delta U_{*},
$$

where $\Delta U_{*}-$ is the voltage fluctuation from the nominal one, relative units.

Traction networks of electrified railways are characterized by wide voltage fluctuations $[2,9]$. This greatly affects the operation of auxiliary machines especially since the voltage of auxiliary winding of the traction transformer is additionally

(c) O. YU. Baliichuk, L. V. Dubynets, O. M. Dukhnovskyi, O. O. Marenych, O. L. Marenych, 2014 
influenced by processes that take place in power and auxiliary circuits of electric or electric locomotive or electric train. As a result of this, the limits of supply voltage fluctuations of auxiliary machines are much wider than on the current collectors. In electric locomotives they are approximately equal to $250 \ldots 460 \mathrm{~V}$ at the nominal value $380 \mathrm{~W}$. For the motor cars with the nominal voltage $220 \mathrm{~V}$ the limits of voltage fluctuations approximately reach $150 \ldots 280 \mathrm{~V}[6,7]$.

Total temperature rise $\sum \tau$ of the stator winding:

$$
\sum \Delta \tau=\theta_{1}+\Delta \tau_{\mathrm{H}}+\Delta \tau_{\mathrm{oH}}
$$

The obtained value $\sum \Delta \tau$ should not be more than the maximum permissible temperature rise for a certain class of thermal resistance of insulation $[1,4]$. As an example of application of the proposed method let us determine $\sum \Delta \tau$ for the motor AOM $-32-2$, which is used for the pump and fan drives of the cabin of AC electric trains series ER9, the $D_{a 1}=14,5 \mathrm{~cm}, l_{1}=9 \mathrm{~cm} \mathrm{[10].} \mathrm{For} \mathrm{this} \mathrm{engine}$ let us perform the following calculation

$$
\begin{gathered}
R_{11} \approx \frac{27}{14,5 \cdot 9}=0,207 \\
R_{12} \approx R_{13} \approx 0,6 \cdot 0,207=0,124 .
\end{gathered}
$$

Efficiency coefficient $\eta=0,78$, nominal power $P_{\text {ном }}=2,2 \mathrm{~kW}$.

Distribution of losses according the type [8]:

Electric losses in the stator $p_{\text {эл1* }}=0,3$;

Electric losses in the rotor $p_{\text {эл2* }}=0,4$;

Losses in magnetic core of the stator $p_{\text {cr* }}=0,15$;

Mechanical losses $p_{\text {мex* }}=0,15$;

Total power losses $\sum p=1,00$.

Consumed power $P_{1}=\frac{P_{\text {ном }}}{\eta}=\frac{2200}{0,78}=2820,5 \mathrm{~W}$;

$\sum p=P_{1}(1-\eta)=2820,5(1-0,78)=620,5 \mathrm{~W} ;$

$\Delta P_{1}=0,3 \cdot 620,5=186,2 \mathrm{~W}$;

$\Delta P_{2}=0,4 \cdot 620,5=248,2 \mathrm{~W}$;

$\Delta P_{3}=0,15 \cdot 620,5=93,1 \mathrm{~W}$;

$\theta_{1}=0,207 \cdot 186,2+0,124 \cdot 248,2+$ $+0,124 \cdot 93,1=80,8^{\circ} \mathrm{C}$
Additional heating under the influence of voltage asymmetry at the minimum voltage in contact network $U_{\text {км min }}=19 \mathrm{~kW} \mathrm{[2]}\left(K_{2 U}=10 \%\right)$ :

$$
\Delta \tau_{\mathrm{H}}=\frac{2 \cdot 10^{2}}{100} 80,8=161,6^{\circ} \mathrm{C}
$$

Voltage fluctuation on the auxiliary AM with $U_{\text {км min }}=19 \mathrm{~kW}$ :

$$
\Delta U_{* \max }=\frac{U_{\text {ном }}-U_{\min }}{U_{\text {ном }}}=\frac{220-150}{220}=0,318
$$

Additional heating of AM through the voltage fluctuations: $\Delta \tau_{\mathrm{Bн}}=60 \cdot 0,318=19^{\circ} \mathrm{C}$.

Total temperature rise of the stator windings:

$$
\sum \Delta \tau=80,8+161,6+19=261,4^{\circ} \mathrm{C} .
$$

The required for this calculation values $K_{2 U}$ and $\Delta U_{*}$ are determined using the graphs that are presented by the Figure 1 and Figure 2. During their construction the dependencies $\Delta U_{*}=f\left(U_{\text {км }}\right)$ and $K_{2 U}=f\left(U_{\text {км }}\right)$ are taken as the linear ones. This assumption is possible because the $K_{2 U}$ and $\Delta U_{*}$ are determined at different values of $U_{\mathrm{rм}}$ through the transformation coefficient of the traction transformer for the winding of auxiliary machines, which is constant value.

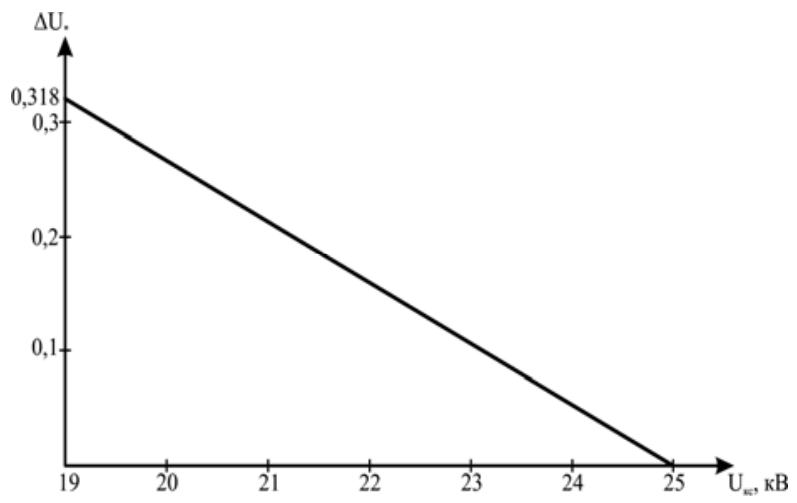

Fig. 1. Dependency $\Delta U_{*}=f\left(U_{\text {кс }}\right)$

For the interval of voltages in the contact network $(19 \ldots 25) \mathrm{kW}$ (Table 1) the calculation is performed $\sum \Delta \tau=f\left(U_{\text {км }}\right)$ similarly.

$$
k_{\text {тр }}=\frac{U_{\text {км ном }}}{U_{\text {АД ном }}}=\text { const },
$$




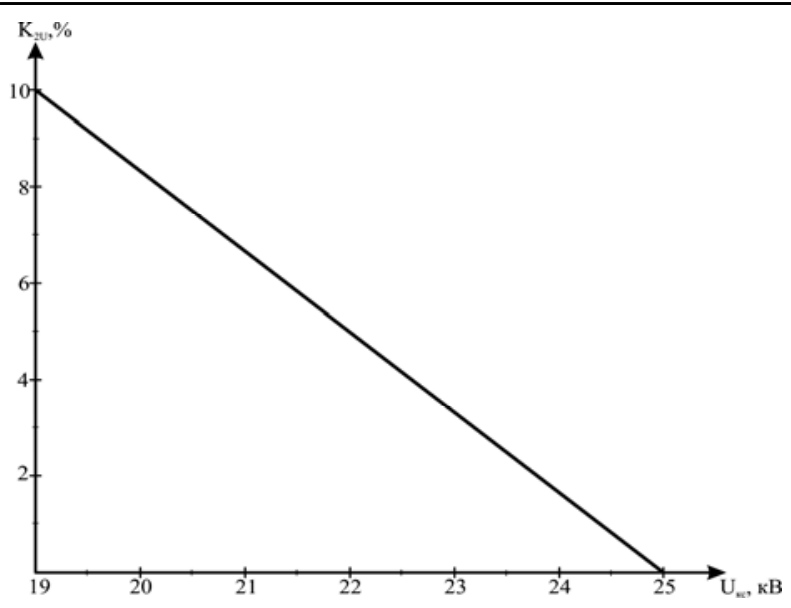

Fig. 2. Dependency $K_{2 U}=f\left(U_{\text {км }}\right)$

where $U_{\text {Ад ном }}$ is the nominal winding voltage for the supply of auxiliary machines. For the AC electric trains of the series ER-9 $U_{\text {АД ном }}=220 \mathrm{~V}$.

\section{Findings}

The Fig. 3 shows the dependence $\sum \Delta \tau=f\left(U_{\mathrm{Kм}}\right)$, which is constructed according to the data of Table 1 .

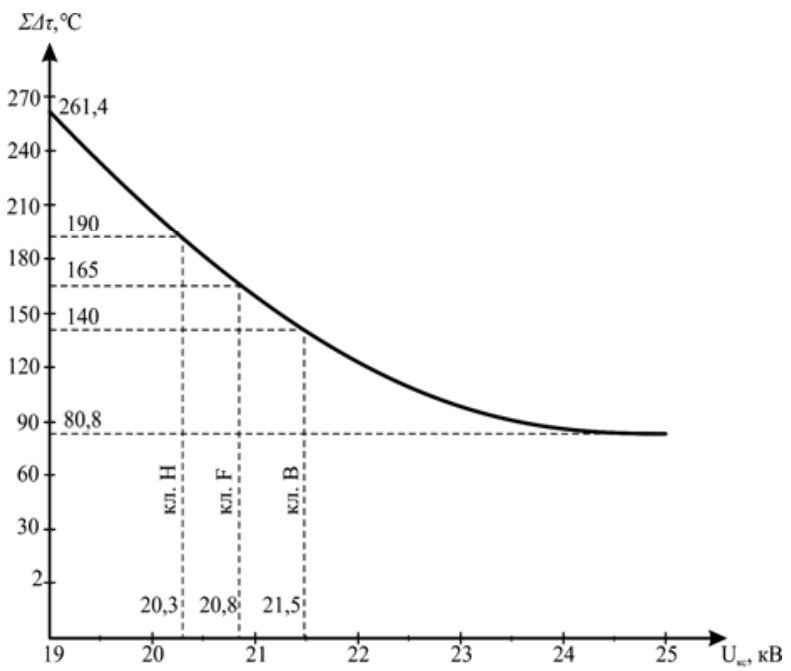

Fig. 3. Dependency $\Sigma \Delta \tau=f\left(U_{\text {км }}\right)$

Maximum permissible temperature rise $\left(140{ }^{\circ} \mathrm{C}, 165^{\circ} \mathrm{C}, 190^{\circ} \mathrm{C}\right)$ of the stator winding (taking into account the fact that the motor AOM $32-2$ is closed unblown) [10], which are indicated in this Figure correspond to a thermal resistance of the insulation B, F, H [1].

The Figure 3 shows that the motor with insulation of class B overheats over the permissible tempera- ture if the stress in the contact network will be for a long time less than $21.5 \mathrm{kV}$. If the engine $\mathrm{AOM}-$ $32-2$ will have insulation of class $\mathrm{F}$ or $\mathrm{H}$, then this voltage should be $20.8 \mathrm{~kW}$ and $20.3 \mathrm{~kW}$ accordingly. Let us call these voltages in contact network the critical ones for auxiliary AM.

$\frac{17,1}{6,3}=2,7$ times more, at $U_{\mathrm{kм}}=19 \mathrm{~kW}-$ in $\frac{161,6}{19}=8,5$ times more. That is why when reaching the critical voltage in contact network it is necessary to take the measures for corresponding reduction first of all the asymmetry coefficient.

Similarly, one can quantify overheat caused by the supply voltage unbalance and its deviation from the nominal value for auxiliary AM of the locomotives and $\mathrm{AC}$ electric trains of all series.

Obviously, at the minimum $U_{\text {км }}=19 \mathrm{~kW}$, which is allowed in the operation, the stator insulation of motor AOM $-32-2$ will overheat beyond the allowable temperature. Even if it has class $\mathrm{H}$, upon the condition that such voltage is sufficiently long in time. The Table 1 shows that at $U_{\text {км }}=23 \mathrm{~kW}$ and less the auxiliary heating of AM with non symmetric voltage in several times exceeds the additional heating than the fluctuation of supply voltage from the nominal value.

\section{Originality and practical value}

It is proposed the method that makes it possible to determine the additional heat of auxiliary machines insulation of electric rolling stock at simultaneous action of such parameters of supply power quality like voltage asymmetry coefficient and fluctuation of voltage supply.

To make sure that the static phase converters are more reliable and economic it will take a lot of time for both their designing and testing and for verifying during operation. The objective preconditions on the feasibility of these studies are not available.

Therefore, at this time the development of recommendations for modernization of the mentioned objects to improve the EQ feeding the auxiliary AM with minimal costs and in short time is the urgent task. 
Dependency calculation $\sum \Delta \tau=f\left(U_{\text {км }}\right)$

\begin{tabular}{l|c|c|c|c|c|c|c}
\hline$U_{\text {км }}$, кВ & 19 & 20 & 21 & 22 & 23 & 24 & 25 \\
$K_{2 U}, \%$ & 10 & 8.2 & 6.51 & 4.9 & 3.25 & 1.55 & 0 \\
$\Delta U_{*}$ & 3.18 & 0.27 & 0.215 & 0.155 & 0.105 & 0.05 & 0 \\
$\Delta \tau_{\text {н }},{ }^{\circ} C$ & 161.6 & 108.7 & 68.5 & 38.8 & 17.1 & 3.9 & 0 \\
$\tau_{\text {вн }},{ }^{\circ} C$ & 19 & 16.2 & 12.9 & 9.3 & 6.3 & 3 & 0 \\
$\sum \Delta \tau,{ }^{\circ} C$ & 261.4 & 205.7 & 162.2 & 128.9 & 104.9 & 87.7 & 80.8
\end{tabular}

In any case, the study of EQ influence (taking into account the real conditions of such parameters as unsinusoidality, asymmetry, voltage fluctuation (VF)) on the aging of thermal insulation of AM of auxiliary devices of ERS caused by its auxiliary heating under the influence of these factors represents scientific and practical interest in terms of improving reliability of locomotives.

\section{Conclusions}

The proposed method makes it possible for the $\mathrm{AC}$ electric rolling stock with rotary phase converters to:

1. Quantify the additional heating of auxiliary asynchronous motors of AC electric rolling stock through the asymmetry of supply voltage and its fluctuation from the nominal value.

2. Identify the critical voltage in contact network, at which the stator insulation of the auxiliary engines of classes B, F, H will overheat above the permissible temperature rise with auxiliary heating, which is caused by the asymmetry of supply voltage and its fluctuation from the nominal value.

\section{LIST OF REFERENCE LINKS}

1. ГОСТ 2582-81. Машины электрические вращающиеся тяговые. Общие технические условия. - Введ. 1983-01-01. - М. : Изд-во стандартов, 1981. $-36 \mathrm{c}$.

2. ГОСТ 6962-75. Транспорт электрифицированный с питанием от контактной сети. Ряд напряжений. - Введ. 1977-01-01. - М. : Изд-во стандартов, 1976. - 3 с.

3. ГОСТ 13109-97. Электрическая энергия. Совместимость технических средств электромагнитная. Нормы качества электрической энер- гии в системах электроснабжения общего назначения. - Введ. 1999-01-01. - М. : Изд-во стандартов, 2002. - 33 с.

4. Дубинець, Л. В. Визначення еквівалентного струму навантаження при випробуванні тягових елекродвигунів на нагрівання без вентиляції / Л. В. Дубинець, Д. В. Устименко, П. О. Лоза // Вісн. Дніпропетр. нац. ун-ту залізн. трансп. ім. акад. В. Лазаряна. - Д., 2008. Вип. 25. - С. 26-29.

5. Избранные вопросы несинусоидальных режимов в электрических сетях предпреятий : монография / И. В. Жежеленко, Ю. Л. Саенко, Т. К. Бараненко и др. - М. : Энергоатомиздат, 2007. - 294 c.

6. Некрасов, О. А. Вспомогательные машины электровозов переменного тока / О. А. Некрасов, А. М. Рутштейн. - М. : Транспорт, 1988 $223 \mathrm{c}$.

7. Некрасов, О. А. Вспомогательные машины электроподвижного состава переменного тока / О. А. Некрасов. - М. : Транспорт, 1967. - 168 с.

8. Новиков, М. Н. Расчет асинхронного двигателя с короткозамкнутым ротором : учеб. пособие / М. Н. Новиков, В. И. Мельников. - СПб. : Петербург. гос. ун-т путей сообщ. (ПГУПС ЛИИЖТ), 2001. - 39 с.

9. Устименко, Д. В. Аналіз впливу зміни режиму роботи на ступінь нагріву ізоляції обмотки якоря електродвигуна поршневого компрессора / Д. В. Устименко, Р. В. Краснов, А. В. Мазур // Вісн. Дніпропетр. нац. ун-ту залізн. трансп. ім. акад. В. Лазаряна. - Д., 2012. - Вип. 42. C. $138-141$.

10. Форум для обмотчиков электродвигателей [Electronic resource]. - Access mode: http://forum.dvigatel.org/. - Title from the screen.

11. Электропоезд ЭР9 / М. Р. Барский, М. Т. Глушков, К. Б. Гончаров, Л. Г. Залесский. - М. : Транспорт, 1964. - 237 с. 
12. Li, W. Evaluating unavailability of equipment aging failures / W. Li, S. Pai // IEEE Power Engineering Review. - 2002. - № 2. - P. 52-54.

13. Montanari, G. C. Aging phenomenology and modeling / G. C. Montanari, L. Simony // IEEE Transaction of Electrical Insulation. - 1993. - № 5. P. 755-776.
14. Shenkman, A. L. Experimental method for syntethis of generalized thermal circuit of polyphase induction motors / A. L. Shenkman, M. Chertkov // IEEE Transactions on Energy Conversion. - 2000. - № 3. - P. 264-268.

\section{О. Ю. БАЛІЙЧУК ${ }^{1 *}$, Л. В. ДУБИНЕЦЬ ${ }^{2}$, О. М. ДУХНОВСЬКИЙ ${ }^{3}$, О. О. МАРЕНИЧ ${ }^{4}$ О. Л. МАРЕНИЧ}

\footnotetext{
${ }^{1 *}$ Каф. «Електротехніка та електромеханіка», Дніпропетровський національний університет залізничного транспорту імені академіка В. Лазаряна, вул. Лазаряна, 2, Дніпропетровськ, Україна, 49010, тел. +38 (056) 3731547 , ел. пошта baliichukaleksei@mail.ru, ORCID 0000-0003-0119-1446

${ }^{2}$ Каф. «Електротехніка та електромеханіка», Дніпропетровський національний університет залізничного транспорту імені академіка В. Лазаряна, вул. Лазаряна, 2, Дніпропетровськ, Україна, 49010, тел. +38 (056) 37315 47, ORCID 0000-0003-0319-4544

${ }^{3}$ Каф. «Електротехніка та електромеханіка», Дніпропетровський національний університет залізничного транспорту імені академіка В. Лазаряна, вул. Лазаряна, 2, Дніпропетровськ, Україна, 49010, тел. +38 (056) 37315 47, ел. пошта daniel214@ukr.net, ORCID 0000-0001-5087-4206

${ }^{4}$ Каф. «Електротехніка та електромеханіка», Дніпропетровський національний університет залізничного транспорту імені академіка В. Лазаряна, вул. Лазаряна, 2, Дніпропетровськ, Україна, 49010, тел. +38 (056) 37315 47, ел. пошта marenich.alexandra@gmail.com, ORCID 0000-0003-4162-1746

${ }^{5}$ Каф. «Електротехніка та електромеханіка», Дніпропетровський національний університет залізничного транспорту імені академіка В. Лазаряна, вул. Лазаряна, 2, Дніпропетровськ, Україна, 49010, тел. +38 (056) 3731547 , ORCID 0000-0003-3602-5851

\section{ВПЛИВ ЯКОСТІ ЖИВЛЯЧОЇ ЕЛЕКТРОЕНЕРГІЇ НА НАГРІВАННЯ ДОПОМІЖНИХ МАШИН ЕЛЕКТРОРУХОМОГО СКЛАДУ ЗМІННОГО СТРУМУ}

Мета. У роботі необхідно з'ясувати питання щодо підвищення надійності допоміжних машин електропоїздів змінного струму при експлуатації в реальних умовах. Методика. Особливістю побудови систем допоміжних машин електрорухомого складу змінного струму є застосування асинхронних двигунів загальнопромислового призначення. Запропоновано інженерний метод визначення впливу несиметрії живлячої напруги та відхилення ії від номінального значення на нагрівання ізоляції допоміжних машин. Результати. Встановлено, що у випадку, коли допоміжні машини електропоїдів змінного струму працюють при коефіцієнті несиметрії напруг $10 \%$ і більше та відхиленні напруги живлення від номінального порядку 0,6 у відносних одиницях, то можливий перегрів їх ізоляції, навіть якщо вона буде мати клас Н. Наукова новизна. Вперше висвітлено питання про сумарний нагрів ізоляції при таких поєднаннях граничних параметрів якості енергії, коли кожен із них сприяє збільшенню нагрівання ізоляції в порівнянні 3 номінальним режимом системи «обертовий фазорозщеплювач - допоміжні машини». Практична значимість. Проведені дослідження дозволяють встановити граничні значення параметрів якості живлячої електроенергії (коефіцієнта несиметрії, відхилення живлячої напруги від номінального значення), при яких додатковий перегрів ізоляції даного класу під впливом зазначених факторів не перевищуватиме встановленого значення.

Ключові слова: перегрів; якість електричної енергії; несиметрія; допоміжні електричні машини; електрорухомий склад; змінний струм 


\section{А. Ю. БАЛИЙЧУК ${ }^{1 *}$, Л. В. ДУБИНЕЦ ${ }^{2}$, А. Н. ДУХНОВСКИЙ ${ }^{3}$, О. А. МАРЕНИЧ ${ }^{4}$, О. Л. МАРЕНИЧ ${ }^{5}$}

\footnotetext{
${ }^{1 *}$ Каф. «Электротехника и электромеханика», Днепропетровский национальный университет железнодорожного транспорта имени академика В. Лазаряна, ул. Лазаряна, 2, Днепропетровск, Украина, 49010, тел. +38 (056) 3731547 , эл. почта baliichukaleksei@mail.ru, ORCID 0000-0003-0119-1446

${ }^{2}$ Каф. «Электротехника и электромеханика», Днепропетровский национальный университет железнодорожного транспорта имени академика В. Лазаряна, ул. Лазаряна, 2, Днепропетровск, Украина, 49010, тел. +38 (056) 3731547 , ORCID 0000-0003-0319-4544

${ }^{3}$ Каф. «Электротехника и электромеханика», Днепропетровский национальный университет железнодорожного транспорта имени академика В. Лазаряна, ул. Лазаряна, 2, Днепропетровск, Украина, 49010, тел. +38 (056) 3731547 , эл. почта daniel214@ukr.net, ORCID 0000-0001-5087-4206

${ }^{4}$ Каф. «Электротехника и электромеханика», Днепропетровский национальный университет железнодорожного транспорта имени академика В. Лазаряна, ул. Лазаряна, 2, Днепропетровск, Украина, 49010, тел. +38 (056) 3731547 , эл. почта marenich.alexandra@gmail.com, ORCID 0000-0003-4162-1746

${ }^{5}$ Каф. «Электротехника и электромеханика», Днепропетровский национальный университет железнодорожного транспорта имени академика В. Лазаряна, ул. Лазаряна, 2, Днепропетровск, Украина, 49010, тел. +38 (056) 3731547 , ORCID 0000-0003-3602-5851
}

\section{ВЛИЯНИЕ КАЧЕСТВА ПИТАЮЩЕЙ ЭЛЕКТРОЭНЕРГИИ НА НАГРЕВАНИЕ ВСПОМОГАТЕЛЬНЫХ МАШИН ЭЛЕКТРОПОДВИЖНОГО СОСТАВА ПЕРЕМЕННОГО ТОКА}

Цель. В работе необходимо выяснить вопрос касательно повышения надежности вспомогательных машин электропоездов переменного тока при эксплуатации в реальных условиях. Методика. Особенностью построения систем вспомогательных машин электроподвижного состава переменного тока является применение асинхронных двигателей общепромышленного назначения. Предложен инженерный метод определения влияния несимметрии питающего напряжения и отклонения его от номинального значения на нагревание изоляции вспомогательных машин. Результаты. Установлено, что в случае, когда вспомогательные машины электропоездов переменного тока работают при коэффициенте несимметрии напряжений 10 \% и более и отклонении питающего напряжения от номинального порядка 0,6 в относительных единицах, то возможен перегрев их изоляции, даже если она будет иметь класс Н. Научная новизна. Впервые освещен вопрос о суммарном нагревании изоляции при таких сочетаниях граничных параметров качества энергии, когда каждый из них способствует увеличению нагревания изоляции по сравнению с номинальным режимом системы «вращающийся фазорасщепитель - вспомогательные машины». Практическая значимость. Проведенные исследования позволяют установить граничные значения параметров качества питающей электроэнергии (коэффициента несимметрии, отклонения питающего напряжения от номинального значения), при которых дополнительный перегрев изоляции данного класса под влиянием указанных факторов не будет превышать установленного значения.

Ключевые слова: перегрев; качество электрической энергии; несимметрия; вспомогательные электрические машины; электроподвижной состав; переменный ток

\section{REFERENCES}

1. GOST 2582 - 81. Mashiny elektricheskiye vrashchayushchiesya tyagovyye. Obshchiye tekhnicheskiye usloviya. [State Standard $2582-81$. Electrical rotating traction machines. General specifications]. Moscow, Standartinform Publ., 1981. 36 p.

2. GOST 6962-75. Transport elektrifitsirovannyy s pitaniyem ot kontaktnoy seti. Ryad napryazheniy [State Standard 6962-75. Electrified transport with overhead system power supply. Electromotive-force series]. Moscow, Standartinform Publ., 1976. 3 p.

3. GOST 13109 - 97. Elektricheskaya energiya. Sovmestimost tekhnicheskikh sredstv elektromagnitnaya. Normy kachestva elektricheskoy energii v sistemakh elektrosnabzheniya obshchego naznacheniya. [State Standard 13109 - 97. Electrical energy. Electromagnetic compatibility of technical equipment. Quality standards of electrical energy in power systems of general purpose]. Moscow, Standartinform Publ., 2002. 33 p.

4. Dubynets L.V., Ustymenko D.V., Loza P.O. Vyznachennia ekvivalentnoho strumu navantazhennia pry vyprobuvanni tiahovykh elekrodvyhuniv na nahrivannia bez ventyliatsii [Determination of equivalent current load 
during the test of traction motors on heating without ventilation]. Visnyk Dnipropetrovskoho natsionalnoho universytetu zaliznychnoho transportu imeni akademika V. Lazariana [Bulletin of Dnipropetrovsk National University of Railway Transport named after Academician V. Lazaryan], 2008, issue 25, pp. 26-29.

5. Zhezhelenko I.V., Sayenko Yu.L., Baranenko T.K., Gorpinich A.V., Nesterovich V.V. Izbrannyye voprosy nesinusoidalnykh rezhimov $v$ elektricheskikh setyakh predpriyatiy [Selected problems of non-sinusoidal regimes in electrical networks of undertakings]. Moscow, Energoatomizdat Publ., 2007. 294 p.

6. Nekrasov O.A., Rutshteyn A.M. Vspomogatelnyye mashiny elektrovozov peremennogo toka [Auxiliary electric machines of the AC electric rolling stock]. Moscow, Transport Publ., 1988. 223 p.

7. Nekrasov, O.A. Vspomogatelnyye mashiny elektropodvizhnogo sostava peremennogo toka [Auxiliary machinery of AC locomotives]. Moscow, Transport Publ., 1967. 168 p.

8. Novikov M.N., Melnikov V.I. Raschet asinkhronnogo dvigatelya s korotkozamknutym rotorom [Calculation of the asynchronous motor with square-cage rotor]. Saint Petersburg, Peterburgskiy gos. un-t putey soobshch. (PGUPS - LIIZhT) Publ., 2001. 39 p.

9. Ustymenko D.V., Krasnov R.V., Mazur A.V. Analiz vplyvu zminy rezhymu roboty na stupin nahrivu izoliatsii obmotky yakoria elektrodvyhuna porshnevoho kompressora [Influence analysis of the change of operation mode on the degree of isolation heating for armature winding of the electric engine piston compressor]. Visnyk Dnipropetrovskoho natsionalnoho universytetu zaliznychnoho transportu imeni akademika V. Lazariana [Bulletin of Dnipropetrovsk National University of Railway Transport named after Academician V. Lazaryan], 2012, issue 42, pp. 138-141.

10. Forum dlya obmotchikov elektrodvigateley (Forum for winding workers of motors). Available at: http://forum.dvigatel.org/ (Accessed 03 March 2014).

11. Barskiy M.R., Glushkov M.T., Goncharov K.B., Zalesskiy L.G. Elektropoyezd ER9 [Electric train ER9]. Moscow, Transport Publ., 1964. 237 p.

12. Li W., Pai S. Evaluating unavailability of equipment aging failures. IEEE Power Engineering Rewiew, 2002, no. 2, pp. 52-54.

13. Montanari G.C., Simony L. Aging phenomenology and modeling. IEEE Transaction of Electrical Insulation, 1993, no. 5, pp. 755-776.

14. Shenkman A.L., Chertkov M. Experimental method for syntethis of generalized thermal circuit of polyphase induction motors. IEEE Transactions on Energy Conversion, 2000, no. 3, pp. 264-268.

Prof. M. O. Kostin, D. Sc. (Tech.); Prof. F. P. Shkrabets, D. Sc. (Tech.) recommended this article to be published

Received: March 03, 2014

Accepted: April 11, 2014 